\title{
Zoobenthic Communities of a High-Density Mat of the Chlorophyta Chaetomorpha linum, in a Hypertrophic Lagoon
}

\author{
M. Lenzi, D. Vani, M. Leporatti Persiano, P. Tomassetti
}

\section{ABSTRACT}

In a non-tidal Mediterranean lagoon, quality and quantity of the zoobenthic communities present in a vast high-density mat of Chaetomorpha linum and the biomass and standing crops of the same mat were estimated seasonally between 2017 and and 2019. The quantity of zoobentos that developed in the mat was very high, with numbers of individuals between $760 \pm 397$ and $1135 \pm 277$ per $\mathrm{kg}$ of alga, in winter and early summer, respectively. The most abundant species in all seasons were those of gammarids and isopods, while blooms of bivalves and the anemone Paranemonia cinerea were occasionally observed. $C$. linum mat showed high potential for the growth of some species of zoobenthos, but most of these decayed during the summer environmental criticalities of the lagoon and the partial decay of the mat.

Keywords: Chaetomorpha linum mat, eutrophication, lagoon, zoobenthos.

Published Online: February 1, 2022

ISSN: $2684-5199$

DOI : $10.24018 /$ ejbio.2022.3.1.319

\section{Lenzi*}

Lagoon Ecology and Aquaculture Laboratory (LEALab), Orbetello, Italy.

(e-mail: lealab1@gmail.com)

D. Vani

Italian Institute for Environmental Protection and Research (ISPRA),

Roma, Italy.

M. Leporatti Persiano

Orbetello Pesca Lagunare Company, Orbetello, Italy.

P. Tomassetti

Italian Institute for Environmental

Protection and Research (ISPRA),

Roma, Italy.

*Corresponding Author

\section{INTRODUCTION}

Over time, the eutrophication of coastal areas, including lagoons, has altered the trophic dynamics and modified food webs, favoring opportunistic organism (Raffaelli et al., 1998).

By their structure, coastal lagoons are naturally disturbed environments that favor opportunistic organisms, which find advantage in the extremely variable conditions of these ecosystems (McLusky \& Elliott, 2007).

The increase in eutrophication in recent decades to hypertrophy values has altered these highly resilient environments, increasing the frequency of dystrophic processes (Lenzi, 2019). The result is that many coastal lagoons are heavily degraded, subject to microphytic, and macroalgal blooms, fishing has collapsed and, as a result of miasma and swarming of chironomids, tourism has also been penalized (Guyoneaud et al., 1998; Lenzi et al., 2013; Čerkasova et al., 2016).

Large microphytic, and macroalgal developments further reduce biodiversity, which is already relatively low in these environments subject to high natural stress. This also applies to the populations of the infauna and zoobenthos that live among the vegetation.

With the summer warming and due to the criticalities caused by the decay of the macroalgal masses, there are extensive deaths of the zoobenthos organisms, which lead to a strong selectivity and a general community impoverishment.

The contribution of this study was to establish density and seasonal flow of zoobenthic populations affecting an extensive and dense mat of the Chlorophyta Chaetomorpha linum, in a hypertrophic non-tidal environment.

\section{MATERIALS AND MethodS}

The authors of the accepted manuscripts will be given a copyright form and the form should accompany your final submission.

\section{A. Study Area}

The Orbetello lagoon is a shallow, eutrophic coastal water body of about $25.25 \mathrm{~km}^{2}$ in the southern Tuscany coast of Italy $\left(42^{\circ} 25^{\prime}-42^{\circ} 29^{\prime} \mathrm{N}, 11^{\circ} 10^{\prime}-11^{\circ} 17^{\prime} \mathrm{E}\right)$. This lagoon has two communicating basins known as West and East, 15.25 $\mathrm{km}^{2}$ and $10.00 \mathrm{~km}^{2}$ respectively, with a $1 \mathrm{~m}$ mean depth (Fig. 1). Three artificial sea-lagoon canals, $0.5-3 \mathrm{~km}$ long and $10-$ $15 \mathrm{~m}$ wide, two in the West and one in the East basin, connect the lagoon with the sea (Fig. 1; SLC 1, 2, 3). Because of the low tidal excursions of the Tyrrhenian Sea and for the length and small width of the three sea-lagoon canals, lagoon water turnover is poor and depends mainly on wind force and direction. Lagoon salinity ranges from 28 to 45 (practical salinity scale), depending on rainfall and evaporation. 
The environment is eutrophic due to fish-farm wastewaters, intermittent streams containing agricultural runoff and civil effluent, and historical input stored in the sediment (Lenzi et al., 2003). Due to high nutrient availability, morphology and low-water-turnover, this lagoon is subject to severe macroalgal proliferation, which can cause dystrophic crises with die-offs (Lenzi et al., 2013). Macroalgal harvesting and sea-water pumping were the first management actions taken to counteract the eutrophication effects. Macroalgal harvesting occurred for 6 months per year and took away from 4000 to 6000 tones of wet macroalgal mass. It was estimated that 6000 tones of macroalgae removed from the ecosystem involved the resuspension of over 15,000 tones of sediments (Lenzi et al., 2013). From 2014 to date, the action to counter eutrophication has mainly been based on the only direct resuspension of the anoxic sediment top-layer, with the aim of oxidizing the sediments and favoring the mineralization of labile organic matter (Lenzi et al., 2017). Sea-water pumping is still practiced annually, between June and August, to promote water turnover, through an input flow coming from two western pumping stations, at the lagoon-mouth of the two western canals (SLC 1,2), and an output flow by the eastern canal (SLC 3; Fig. 1).

During this study we evaluated extent and density of the vast algal mat present in the West basin, and we conducted samplings for the qualitative and quantitative determination of zooplanktonic populations.

\section{B. Estimates of Macroalgal Biomass}

In the West basin of the Orbetello lagoon, a wide highdensity mat of the Chlorophyta Chaetomorpha linum (O.F. Müller) Kützing has persisted stably since 2008 (Lenzi et al., 2013) even during severe dystrophic crises (Sorce et al., 2017) occupying a bottom surface-area between 350 and 450 hectares and moving between east and west by no more than 500-600 m (Lenzi et al., 2020).

C. linum biomass (b) estimates were conducted during 11 monthly trials, between June 2017 and June 2019. The wide mat had previously been divided into 12 areas, marked with flags and geo references, within which 3 samples were collected along a diagonal transect of each area, by avoiding the few and not very large bare bottom holes. Therefore, 36 samples for the whole mat were weighed for each trial. Samples were collected inside a square metal frame of 3600 $\mathrm{cm}^{2}(60 \mathrm{~cm} * 60 \mathrm{~cm})$, drained for $3 \mathrm{~min}$ and weighed directly on board with a portable electronic balance with sensitivity $\pm 0.5 \mathrm{~g}$, according to Sorce et al., (2017). The values were then expressed in $\mathrm{kg}$ wet weight per square meter $\left(\mathrm{kg}_{\mathrm{ww}} \mathrm{m}^{-2}\right)$ using conversion factor according to (1):

$$
\mathrm{b}_{\mathrm{x}} * 10^{-4} * 2.778=\mathrm{b}_{\mathrm{y}}
$$

where $b_{x}$ is the in situ weighed values in $\mathrm{kg}_{\mathrm{ww}}$ per 3600 $\mathrm{cm}^{2}, 10^{-4}$ the conversion factor to bring $\mathrm{cm}^{2}$ to $\mathrm{m}^{2}$, and 2.778 the conversion factor to bring the value to the surface unit of $1 \mathrm{~m}^{2}\left(\mathrm{~b}_{\mathrm{y}}\right)$.

Mat standing crop was then calculated according to the (2):

$$
\mathrm{SC}=\mathrm{b} * \mathrm{CT} * 10^{-3}
$$

where $b$ results from the average of all the estimates values $\left(b_{y}\right)$; CT is the total cover of the substrate by the algal mat estimated through Sentinel-2 satellite images, obtained from Land-Viewer site (EOS DATANANALYTICS, USGS/NASA), and calculated through the Fiji-Image software (Schindelin et al., 2012); $10^{-3}$ is the conversion factor for $\mathrm{kg}$ into tonnes, as standing crop was expressed in tones wet weight $\left(\mathrm{T}_{\mathrm{ww}}\right)$.

\section{Determination of Zoobenthic Populations of the Macroalgal Mat}

Between 2017 and 2018, 4 seasonal trials were conducted (October 2017, January 2018, April, July) aimed at determining the quantity of the main zoobenthic groups present in the macroalgal masses, and at establishing their taxa. Three stations have been established along a transept within the mat of $C$. linum of the West basin. For each trial, two seaweed samples of approximately $500 \mathrm{~g}$ were collected at each of these stations, spaced approximately $50 \mathrm{~m}$ apart. Each sample was the result of mixing a sample of seaweed from the surface of the mat and, with the help of a rake, from the side of the mat closest to the bottom, but not in contact with it, in roughly equivalent quantities. Samples were refrigerated and brought to the laboratory where they were gently dried with bibula paper. Then they were cleaned from the zoobenthos, which was collected, divided by taxa, and counted numerically. All the benthic organisms found were identified at the ISPRA Benthos Ecology laboratory, up to the maximum possible level. The algal masses were further getting dry with bibulous paper and weighed. The quantity of the organisms was then reported to the unit of $1 \mathrm{~kg}$ of wet seaweed.

\section{RESUlTS}

\section{A. Mat Density Estimates}

Monthly means $( \pm \mathrm{SD})$ of biomass for $C$. linum mat and the estimates of SC, between June 2017 and June 2019, are shown in Table I. The extension of the mat fluctuated between 366 and 340 hectares (Fig. 1). Among all available records $(\mathrm{n}=324)$, the mean was $7.69 \pm 3.42 \mathrm{kgww} \mathrm{m}^{-2}$ and the median $5.65 \mathrm{~kg}_{\mathrm{ww}} \mathrm{m}^{-2}$. SC was higher in spring and lower in summer, as expected. The mat was almost surfacing in the part close to the city of Orbetello, and deepened going west, the water column height varying between 100 and $170 \mathrm{~cm}$. 
TABLE I: C. LINUM MAT: BIOMASS (b) MEANS ( \pm SD) IN KGww AND STANDING CROP (SC) IN TONNES WET WEIGHT (Tww), BETWEEN JUNE 2017 AND JUNE 2019; Ind, NUMBER OF ZOOBENTHIC INDIVIDUALS, IN BILLIONS, ESTIMATED AMONG ALL OBSERVED SPECIES; gm, ip, NUMBER OF INDIVIDUALS, IN MILLIONS AND IN BILLIONS, AND RELATIVE WEIGHT IN TONNES, OF GAMMARIDS AND ISOPODS, RESPECTIVELY, BETWEEN OCTOBER 2017 AND JULY 2018.

\begin{tabular}{|c|c|c|c|c|c|c|c|}
\hline & $\begin{array}{c}\mathrm{b} \\
\mathrm{kg}_{\mathrm{ww}} \\
\end{array}$ & $\begin{array}{c}\mathrm{SC} \\
\mathrm{T}_{\mathrm{ww}} \\
\end{array}$ & $\begin{array}{l}\text { Ind } \\
10^{9} \\
\end{array}$ & $\begin{array}{l}\mathrm{gm} \\
10^{6} \\
\end{array}$ & $\begin{array}{c}\text { gm } \\
\text { tonnes }\end{array}$ & $\begin{array}{c}\text { ip } \\
10^{9} \\
\end{array}$ & $\begin{array}{c}\text { ip } \\
\text { tonnes }\end{array}$ \\
\hline June-17 & $11.80 \pm 7.68$ & 35837 & & & & & \\
\hline July-17 & $8.12 \pm 4.27$ & 23666 & & & & & \\
\hline Oct-17 & $7.86 \pm 4.92$ & 26690 & 20.284 & 533.40 & 7.58 & 10.357 & 36.76 \\
\hline Dec-17 & $2.71 \pm 1.83$ & 27307 & & & & & \\
\hline Feb-18 & $8.85 \pm 4.67$ & 25850 & 20.913 & 1680.25 & 23.86 & 5.015 & 17.80 \\
\hline Apr-18 & $9.12 \pm 5.34$ & 35296 & 38.508 & 3070.75 & 43.60 & 1.765 & 6.27 \\
\hline July-18 & $7.05 \pm 5.54$ & 24787 & 28.133 & 1189.78 & 16.89 & 0.644 & 2.29 \\
\hline Oct-18 & $8.23 \pm 4.04$ & 28885 & & & & & \\
\hline Jan-19 & $7.22 \pm 5.00$ & 24721 & & & & & \\
\hline Apr-19 & $7.82 \pm 5.12$ & 27348 & & & & & \\
\hline June-19 & $8.45 \pm 3.76$ & 30026 & & & & & \\
\hline
\end{tabular}

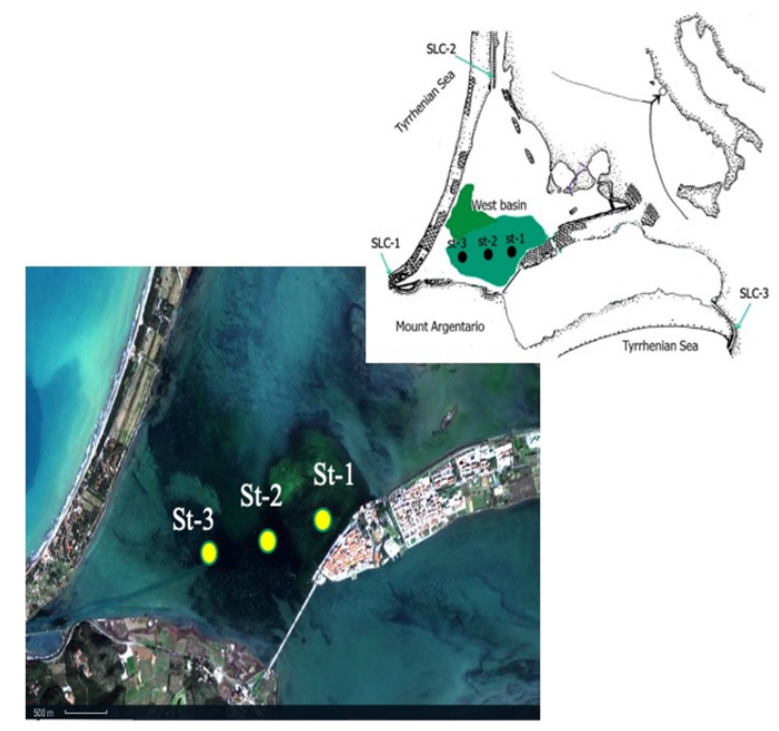

Fig. 1. The Orbetello lagoon. The Chaetomorpha linum mat (green, in the drawing above, and dark, in the satellite image) and the sampling stations (St 1, 2, 3). SLC 1, 2, 3, sea-lagoon canals.

\section{B. Zoobenthos Estimates}

Table II shows the estimates of zoobenthic organisms present per $\mathrm{kg}_{\mathrm{ww}}$ of $C$. linum, collected within the highdensity mat (Fig. 1). The totality of individuals was $760 \pm 397$, $809 \pm 451,1091 \pm 544,1135 \pm 277$ per $\mathrm{kg}$ of seaweed, during the estimates of October-2017, January-2018, April-2018 and July-2018, respectively, with the highest and best distributed values in spring and early summer (first week of July).

The most abundant organisms were the isopods Idotea chelipes, Corophium insidiosum, Dynamene bidentata and Cymodoce truncata, amphipods gammarids Gammarus insensibilis, Melita palmata, Microdeutopus gryllotalpa and Elasmopus rapax, polychaete Ficopomatus enigmaticus, actinias Paranemonia cinerea and Anthopleura ballii, gastropod Hydrobia ventrosa, bivalves Mytilaster marioni and Cerastoderma glaucum. The complete list of species observed in high density $C$. linum mat of the Orbetello lagoon is shown in Table III.
Considering the sampling conducted in the first $20 \mathrm{~cm}$ of the thickness of the $C$. linum mat and in its under-layer closest to the bottom (for a mat thickness between $40 \mathrm{~cm}$ and $90 \mathrm{~cm}$ ), and considering the estimates of the biomass of the algal mat carried out in the same periods, it was possible to calculate the number of zoobenthic individuals (ind) for the entire extension of the mat, and, in particular, those of gammarids and isopods, of which, knowing the average unit weight, it was possible to estimate their biomass present at the time of sampling (standing crop), as reported in Table I. Of course, these data are too few for the extension of the mat to have a statistical significance, and therefore they must be considered indicative of the particular ecosystem condition.

In Table I, together with the SCs of the mat, the total number of zoobenthic individuals present, regardless of the species, and the total number of gammarids and isopods and their relative biomasses are reported for the months considered.

If we consider only gammarids $(20 \pm 6,65 \pm 31,87 \pm 20$, $48 \pm 19$ ind $\mathrm{kg}^{-1}$, for October, January, April, July, respectively), for the average weight per individual of 14.2 $\mathrm{mg}$ (on a sample of 200 ind collected at random), their biomass within the algal mat ranged from a minimum of 7.58 tonnes to a maximum of 43.60 tonnes. The isopods in terms of biomass for the algal mat itself ranged from a maximum of 36.76 tones in October-17 to a minimum of 2.29 tonnes in July-18.

In numerical terms, the organisms present in their entirety per $\mathrm{kg}$ of algae were between a minimum of 336 ind and a maximum of 1791 ind $(933 \pm 440$ ind; Table II). Reporting the averages among the three stations for the 4 months examined, to the relative standing crops of the mat, the organisms were as a whole comprised between 20 and 38 billion individuals (Table I).

The highest density of individuals per $\mathrm{kg}$ of algae and for all algal standing crops was observed between April and the first week of July. The gammarids were more abundant between February and April, while the isopods in October. 


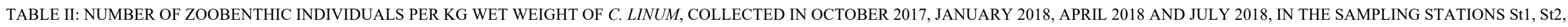
St3, AND RELATIVE MEANS ( \pm SD) FOR MONTH, OBTAINED WITH 6 DATA (TWO DATA FOR STATION)

\begin{tabular}{|c|c|c|c|c|c|c|c|c|c|c|c|c|c|c|c|c|c|}
\hline & & Oct-17 & & & & Jan-18 & & & & Apr-18 & & & & Jul-18 & & & \\
\hline & $\begin{array}{l}\text { St1 } \\
\end{array}$ & St 2 & St 3 & Mean & $\begin{array}{l}\text { St1 } \\
\end{array}$ & St 2 & St 3 & Mean & $\begin{array}{l}\text { St1 } \\
\end{array}$ & St 2 & $\begin{array}{l}\text { St } 3 \\
\end{array}$ & Mean & $\begin{array}{l}\text { St1 } \\
\end{array}$ & St 2 & $\begin{array}{l}\text { St } 3 \\
\end{array}$ & Mean & Mean24 \\
\hline Gp & 12.29 & 375.36 & 273.92 & $221 \pm 187$ & 180.08 & 125.00 & 193.25 & $166 \pm 36$ & 34.50 & 57.00 & 82.28 & $58 \pm 24$ & 13.01 & 10.00 & 28.50 & $17 \pm 10$ & $115 \pm 145$ \\
\hline Ip & 404.70 & 151.41 & 606.94 & $388 \pm 228$ & 359.37 & 112.00 & 109.97 & $194 \pm 143$ & 53.00 & 50.50 & 46.92 & $50 \pm 3$ & 25.39 & 23.00 & 29.00 & $26 \pm 3$ & $164 \pm 235$ \\
\hline $\mathrm{Gm}$ & 17.60 & 24.96 & 16.64 & $20 \pm 5$ & 49.90 & 79.50 & 67.00 & $65 \pm 15$ & 89.00 & 88.00 & 84.82 & $87 \pm 2$ & 40.96 & 50.50 & 52.50 & $48 \pm 6$ & $55 \pm 32$ \\
\hline $\mathrm{Bv}$ & 0 & 0 & 16.05 & $5 \pm 9$ & 0 & 19.50 & 452.96 & $157 \pm 256$ & 0 & 4.50 & 56.38 & $20 \pm 31$ & 65.78 & 9.00 & 44.00 & $40 \pm 29$ & $56 \pm 151$ \\
\hline Pcs & 0 & 380.00 & 0 & $127 \pm 219$ & 679.37 & 0 & 0 & $226 \pm 392$ & 820.00 & 84.50 & 1021.62 & $642 \pm 493$ & 1050.23 & 617.50 & 955.50 & $874 \pm 227$ & $467 \pm 439$ \\
\hline Act & 0 & 0 & 0 & & 0 & 0 & 0 & & 69.00 & 214.48 & 379.09 & $221 \pm 155$ & 195.50 & 67.00 & 112.00 & $125 \pm 65$ & $86 \pm 119$ \\
\hline Pce & 0 & 0 & 0 & & 0 & 0 & 0 & & 0 & 0 & 20.94 & $7 \pm 12$ & 0 & 17.00 & 0 & $6 \pm 10$ & $3 \pm 8$ \\
\hline $\mathrm{Ed}$ & 0 & 0 & 0 & & 0 & 0 & 0 & & 0 & 0 & 9.98 & $3 \pm 6$ & 0 & 0 & 0 & & $1 \pm 3$ \\
\hline Tot Ind & 435 & 932 & 914 & $760 \pm 397$ & 1269 & 336 & 823 & $809 \pm 451$ & 1065 & 505 & 1702 & $1091 \pm 544$ & 1391 & 794 & 1222 & $1035 \pm 277$ & $933 \pm 440$ \\
\hline
\end{tabular}

TABLE III: LIST OF ZOOBENTHOS OBSERVED IN THE HIGH-DENSITY MAT OF C. LINUM OF THE WEST BASIN OF THE ORBETELLO, LAGOON BETWEEN OCTOBER 2017 AND JULY 2018.

Mollusca

Gastropoda

Gibbula adansonii

Tricolia speciosa

Cerithium sp.

Bivalvia

Mydrobia ventrosa

Loripes lacteus

Loripes orbiculatus

Cerastoderma glaucum

Crustacea

Amphipoda

Abra segmentum

Gammarus insensibilis

Microdeutopus gryllotalpa

Melita palmata

Elasmopus rapax

Amphipoda n.d.

Isopoda

Idotea chelipes

Apanthura corsica

Corophim insidiosum

Dynamene bidentata

Cymodoce truncata
Carcinus aestuarii

Decapoda

Decapoda n.d.

Ficopomatus enigmaticus

Polychaeta

Paranemonia cinerea

Anthopleura ballii

Insecta

Chironomus salinarius 


\section{Discussion}

The algal mats are a complex substrate in which numerous zoobenthic populations can settle, some of these species finding, at certain times, extremely favorable conditions to allow their development in very many individuals.

In this study, the distribution of species and individuals was almost never homogeneous along the vast examined mat, except for a few groups which ware often relatively abundant, e.g. gammarids, isopods and gastropods. Other species showed growth blooms at certain times of the year, such as the Actinaria Paranemonia cinerea of which impressive developments were observed in the spring-summer period (Fig. 2), and the Mytilidae Mytilaster marioni, which was abundant especially between autumn and winter. Unfortunately, a large part of this animal biomass ends up decaying during the summer criticality and accumulating energy in the sediments to support further dystrophic processes.

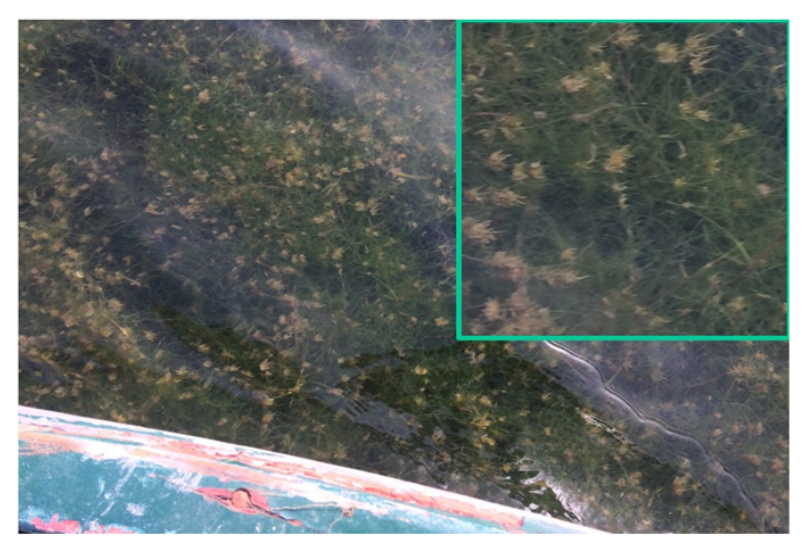

Fig. 2. Paranemonia cinerea on a bed of Chaetomorpha linum in the Orbetello lagoon. Photo taken from the boat; top right, enlargement.

In a recent study, intended to evaluate the impact of sediment resuspension adopted as environmental mitigation to counteract the effects of eutrophication on zoobenthic assemblages in sediments and algal masses, Martelloni et al., (2013) confirmed a close relationship between the number of zoobenthic species in sediment and sediment organic load. Under the worst environmental conditions, when labile organic matter in sediment is high, a greater number of species can be found in the macroalgal mat, which offer a better substrate that can occupy much of the water column. Under such drastic sediment conditions, few species can survive, according to Pearson and Rosemberg paradigm which predict reduced mean body size, shallower distribution of fauna in sediment and reduction of species richness with increasing sediment organic enrichment (Pearson \& Rosemberg, 1978). Therefore, in a vast and dense algal mat, life within the top sediment layer becomes prohibitive for most of the infauna, which, therefore, climbs vertically up the mat in search of better conditions. Until this area also becomes critical during the hottest period of the year.

Regarding the effects produced by frequent disturbance of sediment and algal mats, Martelloni et al., (2013) verified that the zone treated in this way tended to show a reduction in algal mat as well as sediment labile organic matter load. The results showed that the ratio between the number of zoobenthic species present in macroalgal mat and that of the species present in bare bottom sediment decreased in disturbed zones respect to undisturbed. The improvement of sediment quality through the oxidation of organic matter would lead to a reduction of macroalgal mats Lenzi et al., (2010) and would allow an increase in zoobenthic biodiversity Widdicombe et al., (2001), at the same time it would reduce the energy potlatch of the zoobenthic biomass that decays annually with the macroalgal masses, enriching the sediments with labile organic matter. In fact, as shown in Table 1, in a few months it is possible to lose tens of tonnes of isopods and gammarids that only in a minimal part end up in the diet of the fish, as resulting from the stomach contents of Sparus aurata, the species that constitutes $75 \%$ of the catch of this lagoon (Lenzi, preliminary research, unpublished data).

\section{REFERENCES}

Čerkasova, N., Ertürk, A., Zemlys, P., Denisov, V., Umgiesser, G. Curonian Lagoon drainage basin modelling and assessment of climate change impact. Oceanologia, 2016; 58(2): 90-10.

Guyoneaud, R., De Wit, R., Matheron, R., Caumette, P. Impact of macroalgal dredging on dystrophic crises and phototrophic bacterial blooms (red waters) in a brackish coastal lagoon. Oceanologica Acta, 1998; 21: 551- 561 .

Lenzi, M. Hunters of sulfur bloom. Eutrophic non-tidal lagoon environments and dystrophic mechanics. 2019: 116. (Italian).

Lenzi, M., Birardi, F., Calzolai, R., Finoia, M. G., Marcone, F., Nocciolini, $\mathrm{S}$. Hypertrophic lagoon management by sediment disturbance. Marine Pollution Bulletin, 2010; 61(4-6): 189-197.

Lenzi, M., Finoia, M. G., Gennaro, P., Mercatali, I., Persia, E., Solari, J., et al. Assessment of resuspended matter and redistribution of macronutrient elements produced by boat disturbance in a eutrophic lagoon. Journal of Environmetal Management, 2013; 123: 8-13.

Lenzi, M., Palmieri, R., Porrello, S. Restoration of the eutrophic Orbetello lagoon (Tyrrhenian Sea, Italy): water quality management. Marine Pollution Bulletin, 2003; 46: 1540-1548.

Lenzi, M., Persiano Leporatti, M., Gennaro, P. C, N, P, S content of the Chlorophyta Chaetomorpha linum (Müller) Kützing in a vast high density mat of a Mediterranean non-tidal lagoon. Knowl Manag Aquat Ecosyst, 2020; 421: 38.

Lenzi, M., Persiano Leporatti, M., Gennaro, P., Rubegni, F. Artificial top layer sediment resuspension to counteract Chaetomorpha linum (Muller) Kutz. blooms in a eutrophic lagoon. Threee years full-scale experience. Journal of Aquaculture and Marine Biology, 2017; 5(2): 00114.

Lenzi, M., Renzi, M., Nesti, U., Gennaro, P., Persia, P., Porrello, S. Vegetation cyclic shift in eutrophic lagoon. Assessment of dystrophic risk indices based on standing crop evaluations. Estuarine, Coastal and Shelf Science, 2013; 13: 99-107.

Martelloni, T., Tomassetti, P., Gennaro, P., Vani, D., Persia, E., Persiano, M., et al. Artificial soft sediment resuspension and high density opportunistic macroalgal mat fragmentation as method for increasing sedimento zoobenthic assemblage diversity in a eutrophic lagoon. Marine Pollution Bulletin, 2016; 110(1): 212-220.

McLusky, D. S., \& Elliott, M. The Estuarine Ecosystem. Ecology, Threats and Management, $3^{\text {rd }}$ ed. Oxford University Press, 2007: 214.

Pearson, T. H. \& Rosemberg, R. (1978). Macrobenthic succession in relation to organic enrichment and pollution of the marine environment. Oceanographic Marine Biology Annual Review, 16: 229-311.

Raffaelli, D. G., Raven, J. A., Poole, L. J. Ecological impact of green macroalgal blooms. Oceanography and Marine Biology: an Annual Review, 1998; 36: 97-125,

Schindelin, J., Arganda-Carreras, I., Frise, E., Kaynig, V., Longair, M., Pietzsch, T., et Al. Fiji: an open- source platform for biological-image analysis. Nat. Methods, 2012; 9: 676-682.

Sorce, C., Persiano Leporatti, M., Lenzi, M. Growth and physiological features of Chaetomorpha linum (Müller) Kütz. in high density mats. Marine Pollution Bulletin, 2017.

Widdicombe, S., \& Austen, M. C. (2001). The interaction between physical disturbance and organic enrichment: an important element in structuring benthic communities. Limnol Oceanogr, 46(7): 1720-1733. 